\title{
48. COMPARISON OF SITE 374 WITH CIRCUM-IONIAN LAND SECTIONS: IMPLICATIONS FOR THE MESSINIAN "SALINITY CRISIS" ON THE BASIS OF A "DYNAMIC MODEL"1
}

\author{
F. H. Fabricius, ${ }^{2}$ K. O. Heimann, and K. Braune, Geological Institute, Division of Sedimentology and Marine \\ Geology, Technical University, Munich, Federal Republic of Germany
}

\begin{abstract}
When compared with recent published literature, including that resulting from DSDP Leg 13 , the sedimentological investigations of Leg $42 \mathrm{~A}$, Site 374 and the circum-Ionian land sections yield a "dynamic model" for the Mediterranean "salinity crisis" during the late Miocene.

The main features of this model are:

1) Shallow basins with water depths down to 500 meters.

2) An almost continuous supply of oceanic waters and consequently a "Mediterranean" sea level matching approximately the world ocean sea level. Probable (minor) changes in the world ocean sea level, inducing (perhaps major) changes of the Mediterranean Sea level, may have caused the observed cyclicity of sedimentation.

3) A differentiation of lithofacies within the Mediterranean region mainly dictated by water depth and subaerial exposure. The subaqueous sedimentation could have been influenced by systems of currents within the basins and by a fresh water supply (seasonal precipitations and rivers).

Water depths immediately before and after the Messinian were relatively shallow. Basinal subsidence, which occurred from at least Messinian time, with marked activity during the Pliocene and Quaternary, was probably about 1 meter per thousand years.
\end{abstract}

\section{INTRODUCTION}

Site 374 is near the center of the Ionian Basin which is surrounded by land areas with late Miocene marine and evaporitic sediments: Sicily, Tunisia, the Greek mainland, and the Ionian Islands.

Geophysically on- and offshore late Miocene strata can be linked; they are generally thicker toward the present center of the basin. On the basis of the interpretation of geophysical data (Montadert et al., 1970) and on the evaporites cored during DSDP Leg 13, the previously held interpretation, that their equivalents exposed on shore were deposited sporadically in isolated lagoons, was abandoned.

The general sequence of circum-Mediterranean late Miocene sediments is as follows: Tortonian marine marls are topped by dolomitic marls, diatomites, or diatomitic marls and/or shallow water carbonates. These facies grade into sulfates, with dolomitic argilla-

\footnotetext{
${ }^{1}$ In memory of Max Pfannenstiel, a great geologist and teacher of a dynamic Mediterranean geology.

${ }^{2}$ Science Editor's Note: The discussion part of this paper largely presents the viewpoint of one of the Leg 42A shipboard scientists, F. Fabricius, whose interpretations of the drilling results conflict with those of the rest of the shipboard party. In the interests of freedom of scientific expression within the volume, the chief scientists and science editor have not critically reviewed this contribution, but have included it as written.
}

ceous and/or calcareous intercalations. The onshore evaporites are mostly restricted to the sulfate facies. Halite, topped by sulfates, was deposited regionally only in Sicily. Towards the end of the late Miocene "salinity crisis" the initial facies was deposited again: in basinal settings the sulfates are topped by dolomitic marl, in marginal settings the sometimes very thin dolomitic marls are topped by a Pliocene high-carbonate normal marine facies, the "Trubi" limestone.

There is now almost complete agreement concerning the depth of deposition of the sulfate sediments. They were deposited in very shallow, intertidal, and subaerial environments. The depth of the Mediterranean basin(s) at the end of the Tortonian, however, is vigorously debated.

Hsü et al. (1973) were the main proponents of an à priori deep basin - one very much like the present Mediterranean Sea - hypothesis. Most of the European geologists advocated that a much shallower ba$\sin (\mathrm{s})$ existed at the time the Messinian "salinity crisis" began.

The terms "deep basin" and "shallow basin" have been used very subjectively. Hsü et al. (1973a) spoke of a "deep basin" when referring to depths between 2000 and 4000 meters. Schreiber and Friedman (1976, quoting Decima [personal communication]) regard "about 600 meters" as "fairly deep" and as a "deep 
water state." Nesteroff (1973), who originally proposed the "shallow water model" thought in terms of "100 and 500 meters below sea level."

In the present paper, by "deep basins" we mean depressions of more than 1000 meters below world ocean sea level; we consider a "shallow basin" one that is 500 meters or less, and the intermediate range is covered by the term "moderately deep basin."

Knowledge of the absolute depth(s) of the basin(s) is essential for the reconstruction of the Messinian geography and our understanding of the mode of formation of the evaporitic sediments. Morphology and configuration of the basin(s) depend on geodynamic processes. Instead of "deep-basin model" we propose the term "static model" (static since the Tortonian; subsidence equalling only the thickness of Messinian and Pliocene sediments); instead of "shallow basin model" we prefer the expression "dynamic model" because the present configuration and depth of the Mediterranean Basin are attributed to post-Tortonian geodynamics.

\section{COMPARISON OF LITHOLOGY AND FACIES AT SITE 374 WITH CIRCUM-IONIAN LAND SECTIONS}

\section{Types of Evaporitic Rocks}

Dolomitic marls, gypsum laminates, selenites, nodular gypsum, alabastrine gypsum, and detritic calcium sulfate sediments occur on the Ionian Islands, in Sicily, and/or in cores from Site 374. Usually, dolomitic marls are not considered to be true "evaporitic sediments." Nevertheless, as they form the first stage (as well as the last stage) of the Messinian event, we include these sediments in our description of the evaporitic facies. An idealised distribution for the sulfate facies is shown in Figure 1. For further details, see also Garrison et al. (this volume).

\section{Dolomitic and Dolomite Marls}

Surface marls from the present-day bottom of the eastern Mediterranean have about $8 \%$ dolomite (Milliman and Müller, 1973) and Quaternary marls from the same area have about $12 \%$ dolomite. A dolomite content of about $10 \%$, as present in Messinian sediments on the Ionian Islands, is thought to represent an average percentage for this period (Braune et al., 1973). We therefore assume that sediments containing dolomite contents of much above $10 \%$, and not accompanied by high percentages of terrigenous quartz and feldspar, probably formed in situ by processes of early diagenesis. In high-carbonate sediments (e.g., Site 374, Core $11^{3}$ ), the presence of dolomite may also be a result of a later diagenesis.

In general, these dolomites contain an excess of calcium of $5 \mathrm{~mol} \%$ (see also Müller, this volume). The ranges of $\delta 0^{18}\left( \pm 3.12\right.$ to $3.76 \%$ o ) and $\delta 6 \mathrm{C}^{13}$-values ( -4.02 to $-6.69 \%$ o Hahn-Weinheimer et al., this vol-

\footnotetext{
${ }^{3}$ Science Editor's Note: This core was originally thought to be Messinian, but is now referred to the lower Pliocene, see Site 374 Report, this volume.
}

ume) are interpreted as indicative of evaporitic conditions.

Frequently dwarfed planktonic foraminifers occur in these dolomite-bearing marls (see Figure 2) which suggest a marine influence but an "abnormal" ecological situation. On the basis of study of onshore sequences, we interpret this dolomitic argillaceous facies as transitional between normal marine marls and oozes and the sulfate stage of the evaporitic cycles (Figures $3,4)$.

Probably this dolomitic facies results from a $\mathrm{Mg} / \mathrm{Ca}$ ratio higher than in normal seawater. High $\mathrm{Mg} / \mathrm{Ca}$ ratios may be caused by the entrapment of calcium, either by the shallow water calcareous sediments (reef limestones, oolites, etc.) during the "regressive" stage (= increasing salinity) or by contemporaneous or preexisting calcium sulfate precipitation during a stable state of evaporation or a "transgressive" stage (= decreasing salinity). Dwarfed microfossils, found in many of the dolomitic marls of the DSDP cores, indicate that the dolomite marls were formed under water and probably below normal wave base. Sulfate beds (mainly gypsum) interbedded in or alternating with these dolomite marls, generally also belong to the subaqueous sulfate facies. In a "regressive" phase, the dolomitic marls may be exposed to the subaerial environment (e.g., salt flat or sabkha). In this case, gypsum may be transformed into anhydrite, and/or anhydrite may occur diagenetically as displacive nodules.

The appearance of Lüneburgite $\left[\begin{array}{ll}\mathrm{Mg}_{3} & \left(\mathrm{PO}_{4}\right)_{2}\end{array}\right.$ $\mathrm{B}_{2} \mathrm{O}(\mathrm{OH})_{4} \times \mathrm{H}_{2} \mathrm{O}$ ] within the dolomite marls topping the sulfates in Site 374 (Müller and Fabricius, this volume) is enigmatic, but characterizes a rather late phase of evaporation.

\section{Gypsum Laminites (or Lamellar Gypsum)}

We use the term "gypsum laminites" to mean finegrained, finely stratified sediments which still show the remains of primary features (Figures 5,6 ) and thus provides evidence of its possible genetic origin. Consequently, these differ from a stratified gypsum arenite. Heimann (1977) interprets needle-shaped crystals found parallel and subparallel to, and irregularly arranged on the bedding planes as primary features. So the gypsum laminates correspond to a chemical (primary) deposit (cf. Ogniben, 1957). The needles, after sedimentation in shallow water, were immediately intensively fractured, except for those which survived. The internal texture of the laminites may be either normally graded, inversely graded, or ungraded (often accompanied by microcrystalline carbonate).

Experiments have been conducted to produce isothermally grown crystal crops and these, with some precaution, may be transferred to naturally grown crops. Heimann (1977), on the basis of Edinger's (1973) observations, suggested the following processes for the formation of primary gypsum laminates.

1) Inversely graded gypsum laminites: The first crop of crystals from supersaturated brines grow under the influence of large temperature and volume variations. This produces large numbers of crystal nuclei 

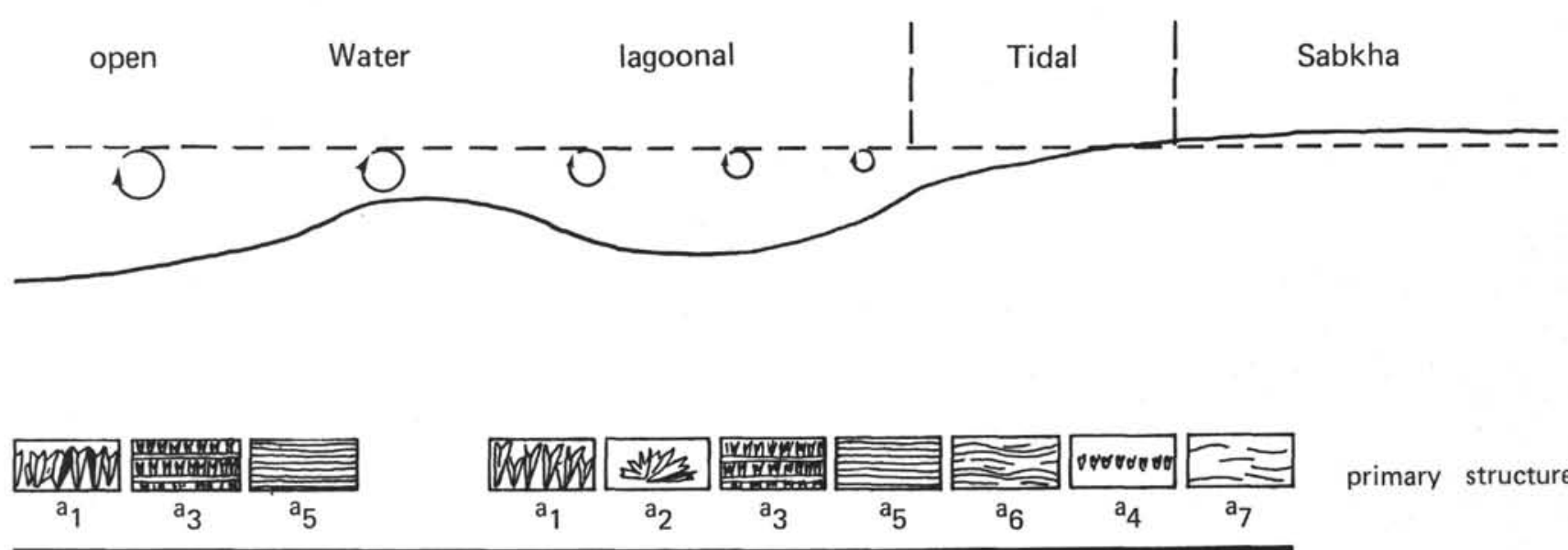

primary structures

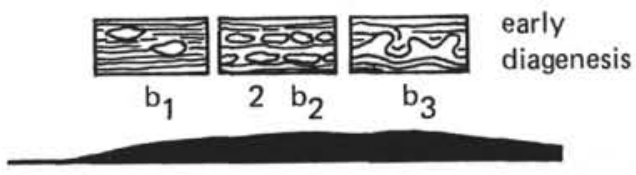

detritus

Figure 1. Environments of evaporitic rocks; all of which may be subject to early (to late) diagenesis (or metamorphism); $a_{1}=$ Selenite $(\mathrm{cm}-\mathrm{m}) ; a_{2}=$ selenite ("cavoli"-structures); $a_{3}=$ centimetric selenite with narrow standing laminites; $a_{4}=$ mm-selenites; $a_{5}=$ laminates (+algal structures); $a_{6}=$ undulating laminae (+algal structures); $a_{7}=$ partly destroyed laminae $; b_{1}=$ laminae + rare nodules; $b_{2}=$ nodules + laminae $; b_{3}=$ enterolitic structures.

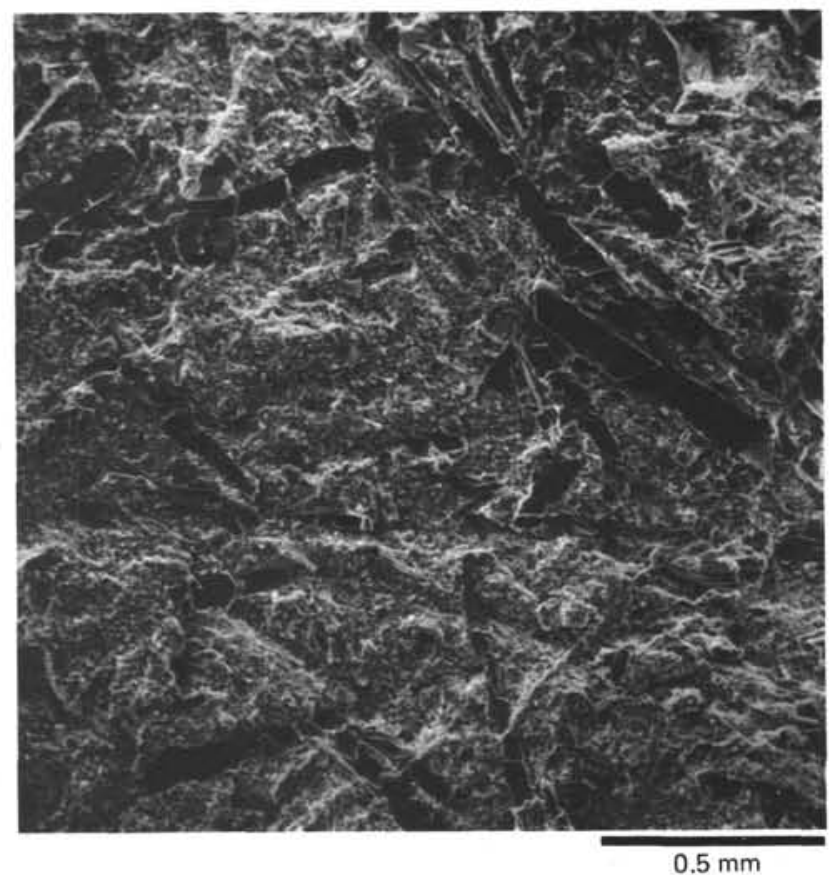

Figure 2. Dolomitized foraminiferal sediment; uppermost Messinian; 374-11-1, 120-124 cm; dark areas are diagenetic concentrations of argillaceous matter; bright spots are dolomitized planktonic foraminifera. Bar scale $=4 \mathrm{~mm}$ (see science editors note, $p$. 928).

and thus great numbers of rather small crystalline particles. The subsequent crops grow under relatively stable conditions and produce fewer nuclei and larger crystals.
2) Normally graded gypsum laminae: Continuous evaporation results in rising percentages of sodium ions in the brine. This causes a decrease in particle size of the successive gypsum crystal depositions.

3) Ungraded gypsum laminae: These may represent rather constant concentrations within the brine, possibly combined with mixing of the gypsum grains with carbonates by shallow water movements.

What we find today, in all three cases, are mainly diagenetically altered sediments with traces of their primary textures. These sediments may be accompanied by interlayers containing remains of organic (algae) (Figures 7 to 10), or of inorganic (calcareous and clayey) material. If the sediments occur as pure gypsum laminites, lamellar texture is brought about by abrupt changes in grain size.

Thus, the descriptive term "gypsum laminite" may encompass several different modes of formation under varying environmental conditions.

\section{Selenite}

This variety of gypsum consists of primary gypsum crystals growing side-by-side in close contact with their c-axis normal to the bedding planes. In "cavoli"'(Richter-Bernburg, 1973) or "scutiform" structures the angle between the c-axis and the bedding plane may be modified, due to conditions of formation.

Selenites occur in millimetric up to metric dimensions. They seem to form under very specific conditions: (a) rather constant brine concentrations following the initial precipitation of needle-shaped crystals which, accompanied by their detritus, may form the underlying gypsum laminations; and (b) associated 


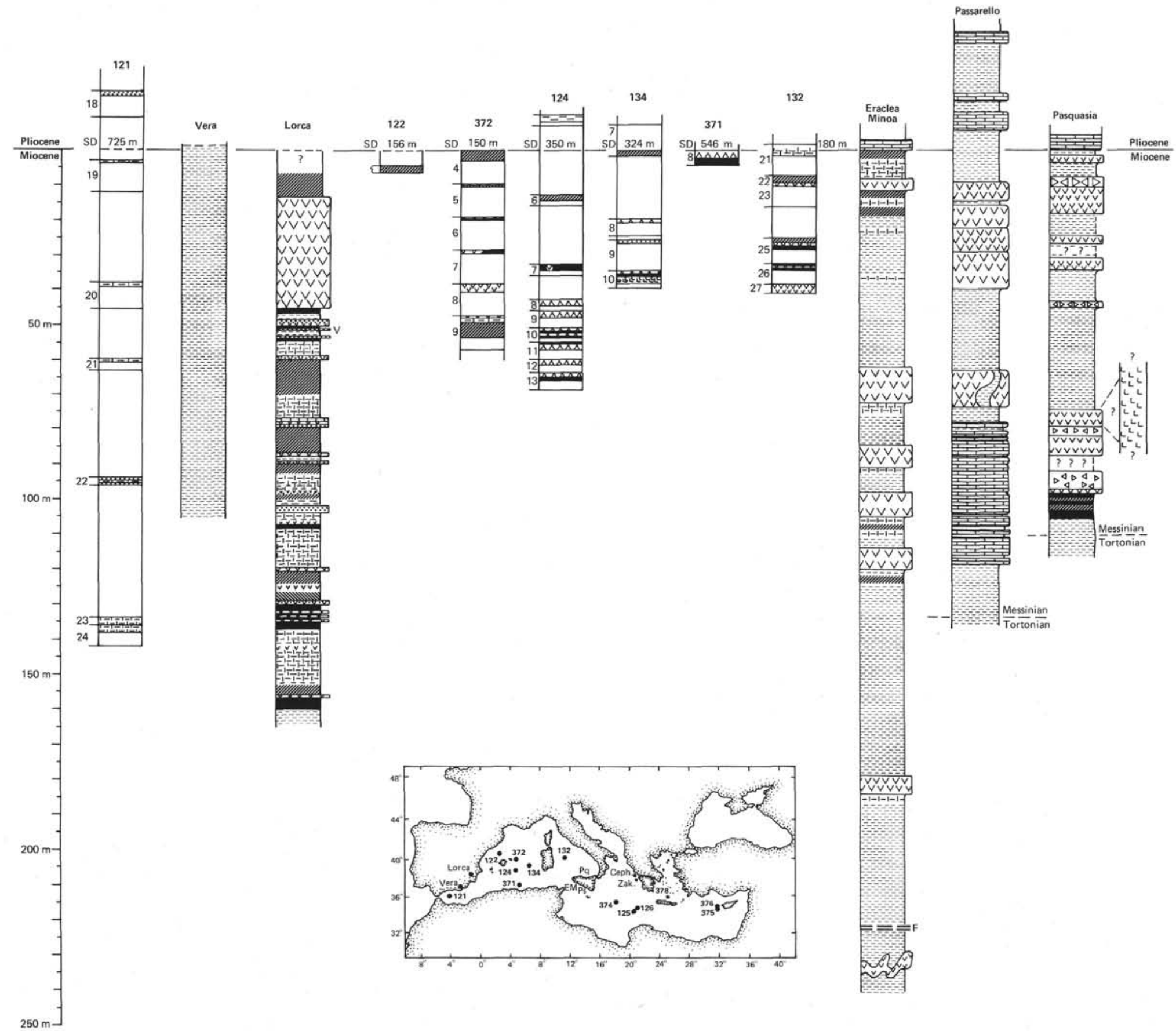

Figure 3. Stratigraphic sections of Messinian sequence at DSDP sites (Legs 13 and $42 \mathrm{~A}$ ) and land section (Western Mediterranean); map shows locations; see figure 4 for explanation of symbols. 


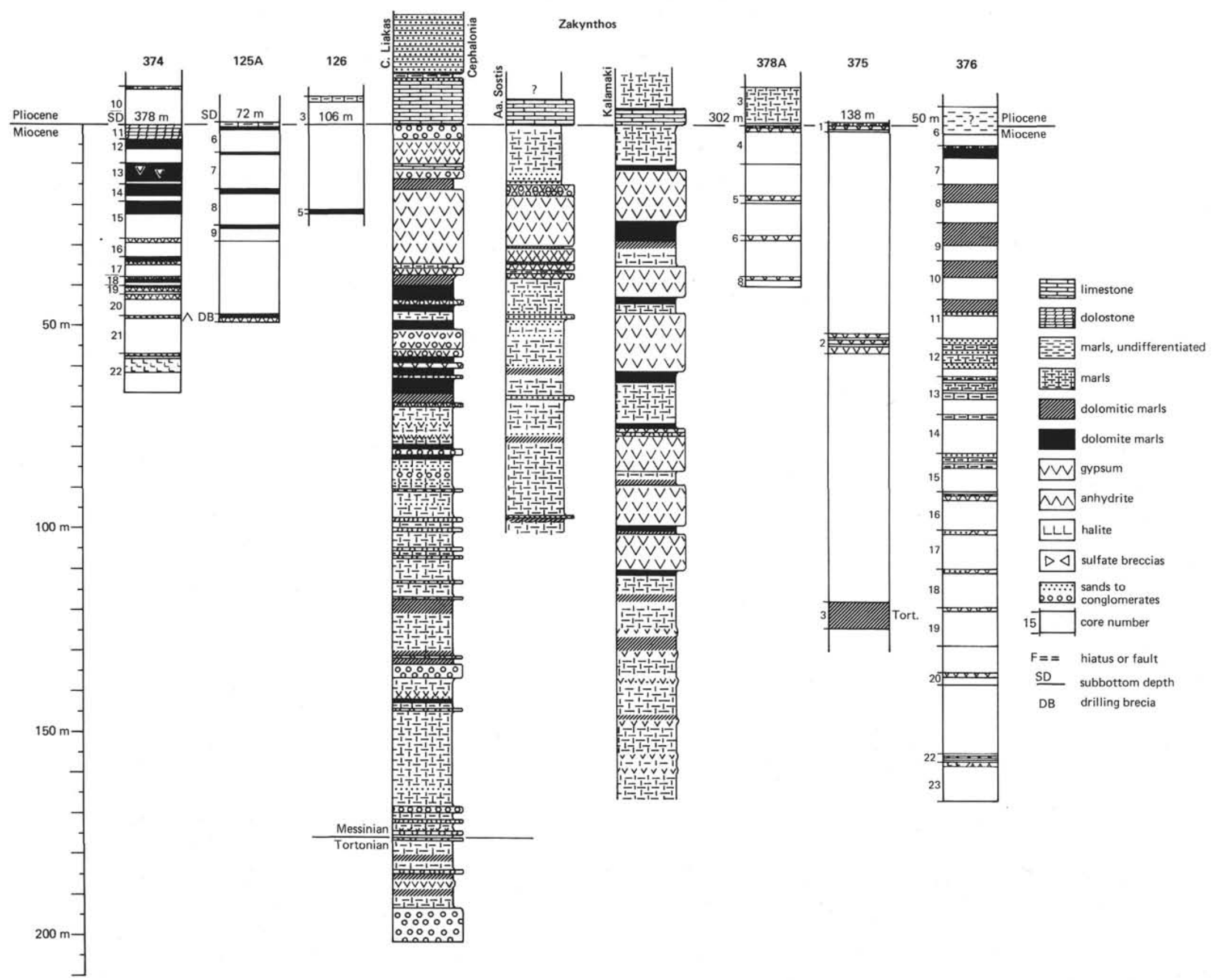

Figure 4. Stratigraphic sections of Messinian sequence at DSDP sites (Legs 13 and $42 A$ ) and land sections (Eastern Mediterranean). See Figure 3 for locations. 
F. H. FABRICIUS, K. O. HEIMANN, K. BRAUNE

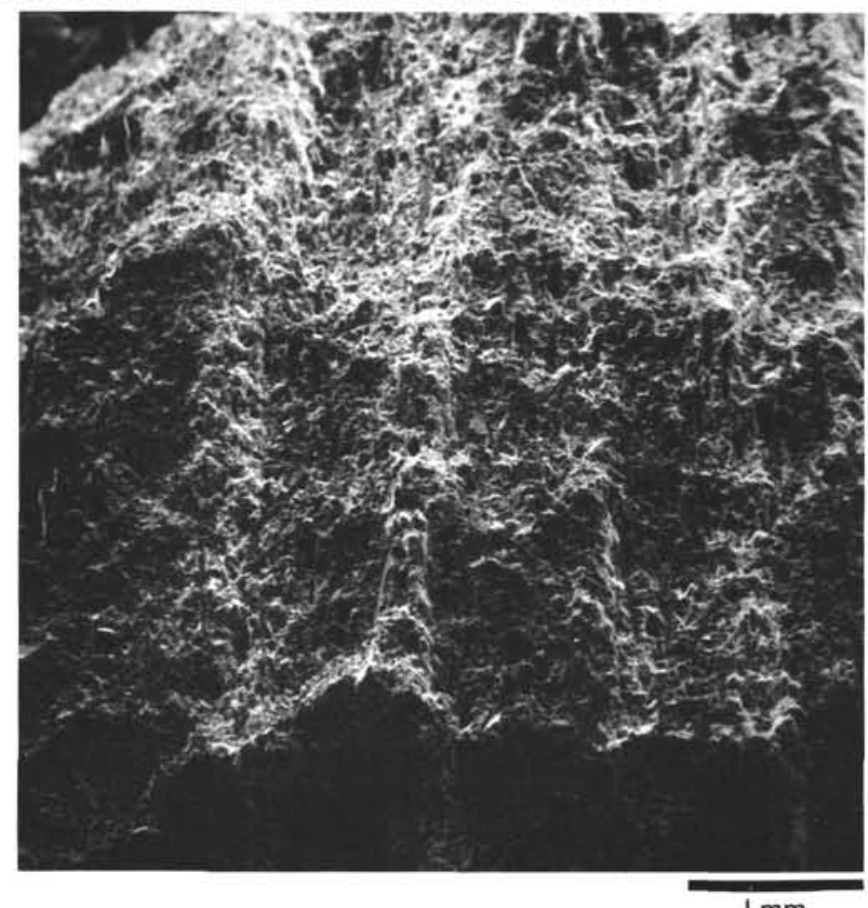

$1 \mathrm{~mm}$

Figure 5. Cross-fracture through gypsum laminite, Messinian. Gypsum needles parallel to bedding plane (vertical); Corfu.

with quiet waters out of reach of waves and currents. This may mean some decimeters of water-depth or even subaerial exposure in nearshore areas, but surrounded by brine (see Morris and Dickey, 1957).

The length of crystals seems to be determined by the duration of the appropriate conditions of concentration, while short intervals of detrital influx (documented by thin, marly films within rows of selenite crystals) seem to be of minor importance. More important-and quickly occurring-influxes of small detrital particles may, however, greatly influence the subtle chemical equilibrium and lead to laminated interlayers, as do rapidly increasing concentrations.

\section{Nodular Gypsum}

This variety of gypsum seems in most cases to be the product of early diagenesis. Displacive anhydrite in subaerially exposed carbonate sediments (of sabkha environments) is subsequently transformed into gypsum (Butler, 1969; Curtis et al., 1963; Kinsman, 1965, 1969; Shearman, 1966, 1971). Nodular elements may occur

a) occasionally (1-6 per $\mathrm{m}^{2}$ of outcrop);

b) in masses (but not touching each other, laminations still present);

c) arranged in layers (laminated interlayers still present); or

d) coalescing to form enterolitic structures (eventually causing the complete disappearance of accompanying laminations).

\section{Banded Gypsum}

We use the term "banded gypsum" for calcium sulfate sediments formed of centimetric layers. Because

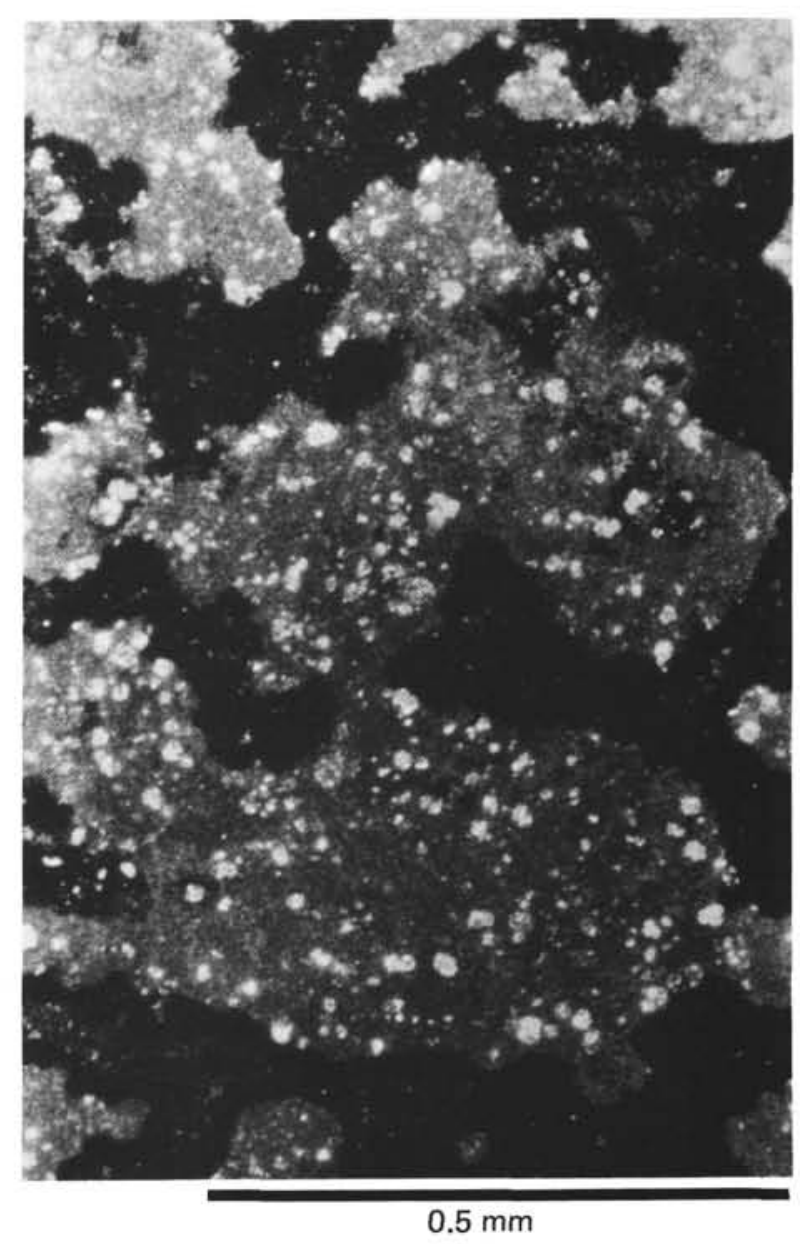

Figure 6. Gypsum laminite, Messinian; fractured parallel to bedding plane, showing gypsum needles oriented randomly in and parallel to bedding plane; Corfu.

of the rare occurrence of mud and calcite grains, some of the banded gypsum is "diagenetically altered gypsum arenites." They are mostly light blue-gray and centimetric marly interlayers occur only occasionally.

\section{Alabastrine Gypsum}

Alabastrine gypsum represents a late diagenetic to low-grade metamorphic variety (Garrison et al., this volume). This occurs in former laminites and banded gypsums as well as in nodules. Schreiber (1974) describes it from the apex of folds in Sicily, and attributes its origin to tectonic stress.

\section{Detritic Gypsum}

Gypsum arenites may occur as almost pure gypsum detritus or accompanied by varying percentages of biogenic detritus or other calcareous argillaceous, and siliceous (chert) grains.

In places on land, gypsum conglomerates which are traceable to their original deposit, or pure gypsum breccias, which were clearly derived from selenite "lawns" in their immediate vicinity provide evidence of synsedimentary erosion. Breccias composed of sele- 


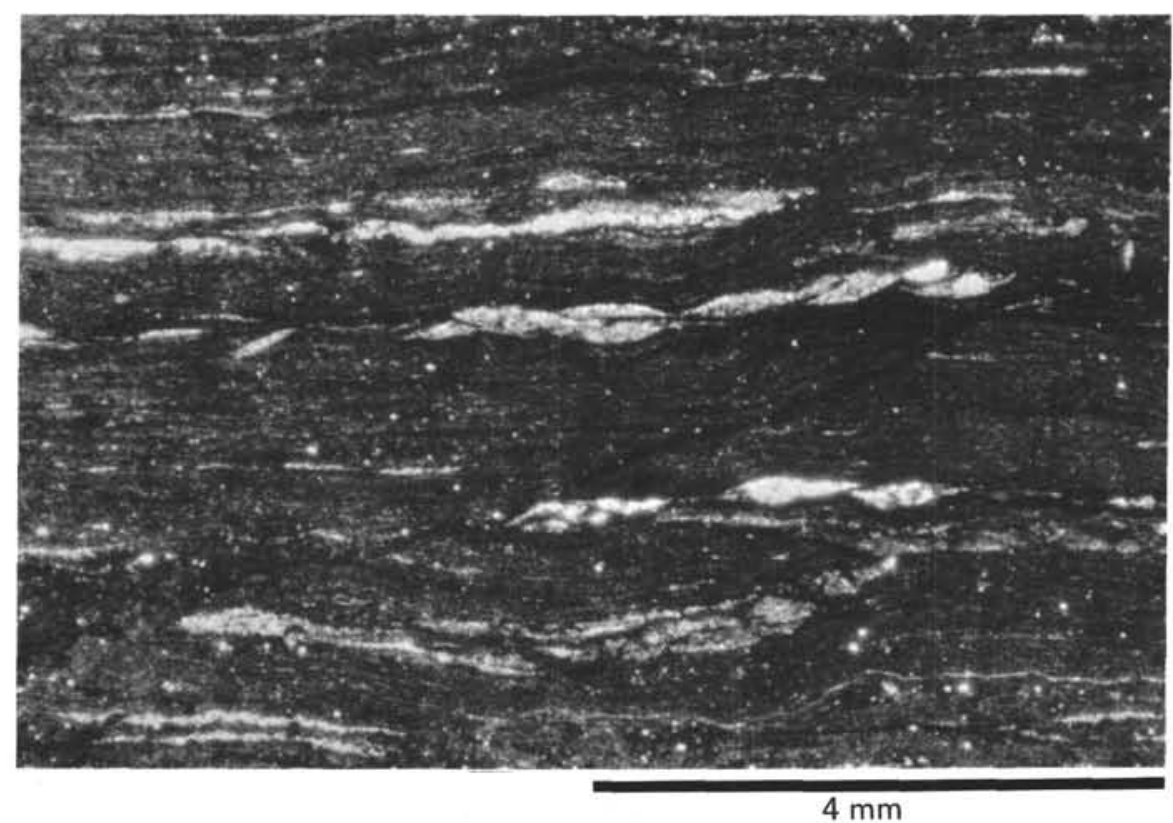

Figure 7. 374-17-1, 47-50 cm; Messinian. Algal dolomite with gypsum; fenestrate structures (light) between dolomite algal laminae (dark).

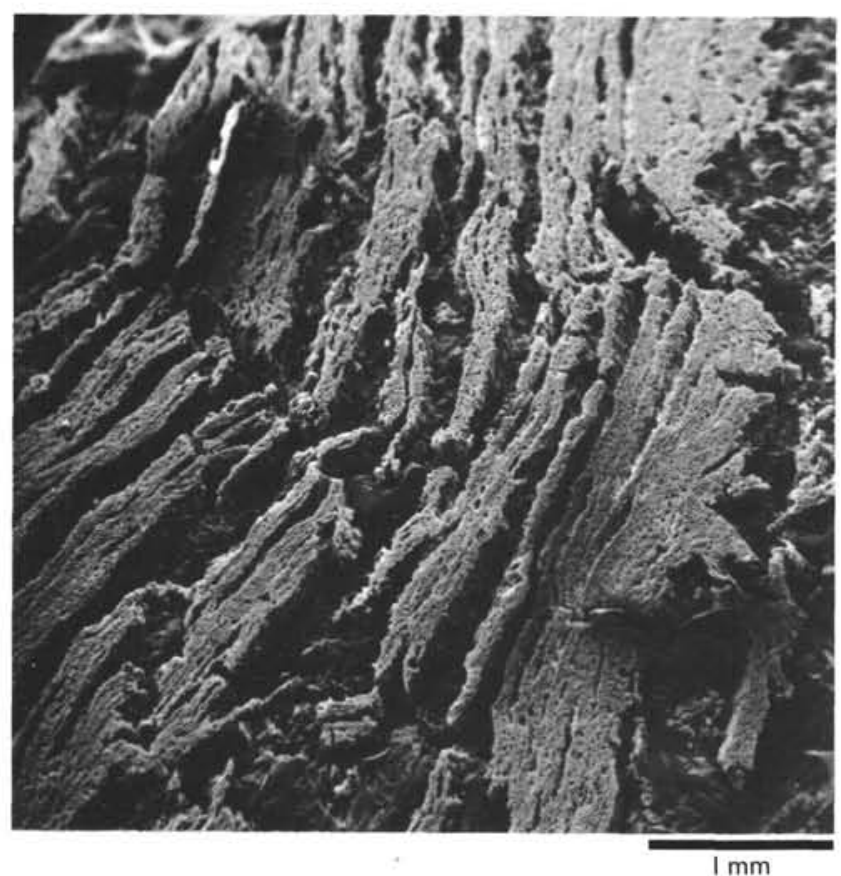

Figure 8. 374-17-1, 42-46 cm; Messinian. SEM-micrograph of "algal laminate." Cross-section, polished and etched. Bar scale $=1 \mathrm{~mm}$.

nitic, lamellar, and "s-m-t"- or "s-m-c"-components represent reworked evaporitic cycles (see below). Breccias showing higher percentages of contemporaneous carbonate elements must have had their source close to the border between the sulfate and carbonate facies.

Finally, in some cases, admixtures of characteristically rounded non-gypsiferous components may be traced to a source in the hinterland and document a nearshore or littoral formation.

\section{EVAPORITIC CYCLES AND NUMBER OF CYCLIC EVENTS}

\section{Cyclicity}

Evaporitic sediments occur in cycles within the Messinian sediments of the Mediterranean area. Controlled and modified by local conditions (see below), they may be represented as transgressive or regressive cycles.

If a cycle is purely controlled by changes of concentration in a given depth of brine, it may be called an "evaporitic cycle" (see below). The results of such a concentration-controlled evaporation process were described by Heimann and Mascle (1974). Minor oscillations resulted in so-called "sequences mineures," while long-lasting evaporitic conditions are responsible for "sequence majeure." The "sequence mineure", is composed of sand $(\mathrm{s})$, marls $(\mathrm{m})$, tripoli $=$ diatomite $(\mathrm{t})$, and carbonate (c). S-m-t and s-m-t-c sequences occur in both the basal and upper parts of the Messinian interval.

In some outcrops, however, such as the Eraclea Minoa section in Sicily and the Paghi section on Corfu, the "sequences mineures" within the major cycles are composed of sand, marl, and carbonate (needleshaped aragonite and block calcite). Diatoms are rare and are concentrated in the blue-grayish marls rather than in the whitish (carbonate) interlayers. These carbonates in the basal, as well as in the upper Messinian beds, are true evaporitic sediments (Neev, 1963; Kinsman, 1964; Wells and Illing, 1964; Busson et al., 1972; Busson and Noél, 1972). 


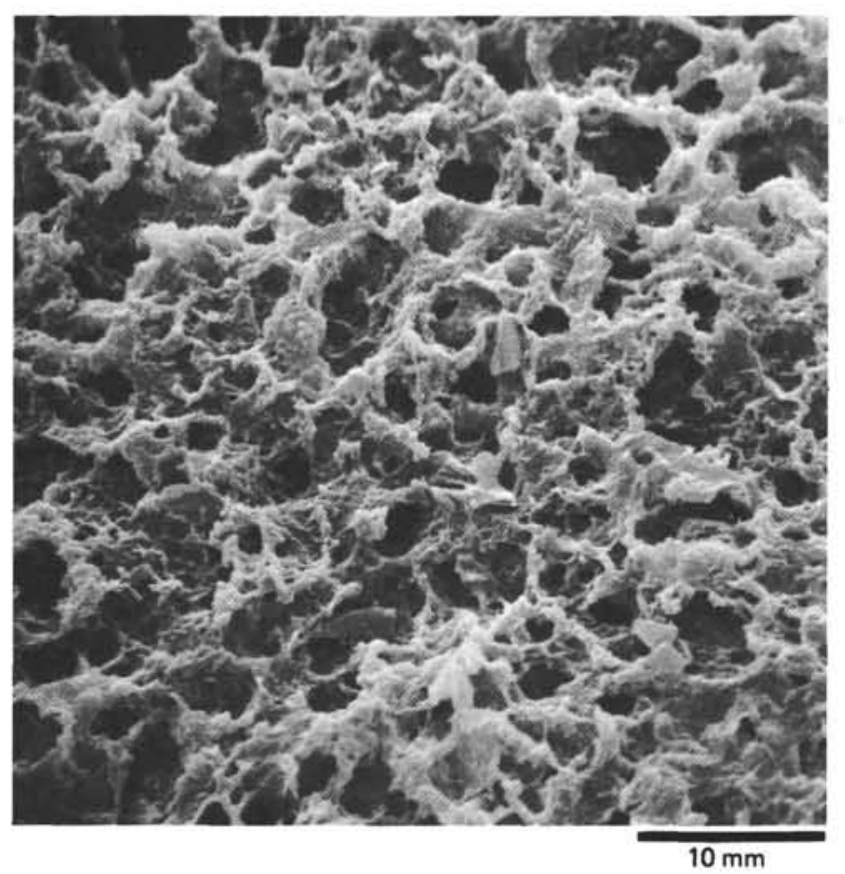

Figure 9. 374-17-1, 37-47 cm; Messinian. "Algal laminite," SEM-photomicrograph of cross-section of a lamina showing casts of globoid "algae."

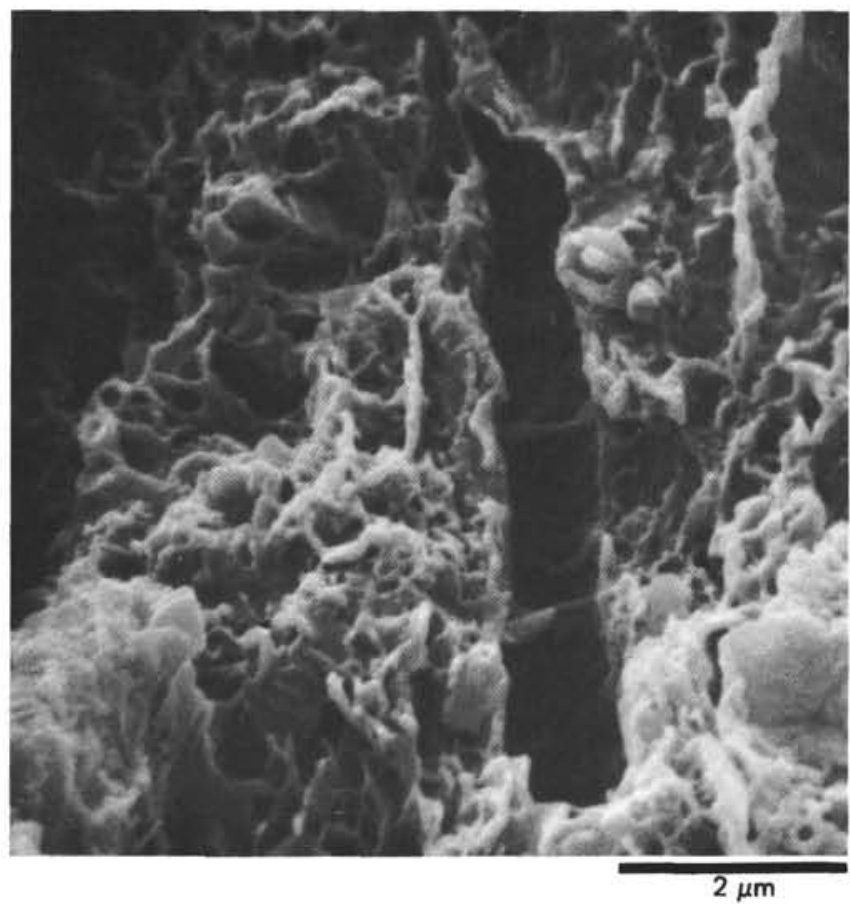

Figure 10. 374-19-1, 140-144 cm. SEM-micrograph of "algal laminite," cross-fracture; cast of a filiform "alga," oriented parallel to bedding plane. Bar scale $=2 \mu \mathrm{m}$.

Gypsum laminites, with or without carbonate- and gypsum-rich interbedding, together with decimetric to metric selenite beds complete minor sequences to a major cycle which, when ideal circumstances prevailed, was completed by halite and bitterns (Heimann and Mascle, 1974).

A good example of sedimentary rhythms and cyclic events is the outcrop of Eraclea Minoa (see Figures 3, 4) west of Argrigento, Sicily. Here, major cycles are well exposed, showing the sequence of minor rhythms, laminites, and selenites in perfect repetition, and the contact between the Messinian marls and the Pliocene marly carbonates is preserved. Less perfect, but equally interesting, is the outcrop near the ancient sulfur mine of Grottacalda (in the northeastern part of the Great Sicilian Neogene Basin) which shows five to six major cycles (Heimann and Mascle, 1974). In other outcrops some of these cycles are incomplete. Depending upon local conditions, they may be represented, for example, by minor sequences combined with laminites (Pasquasia, Figures 3,4) or by laminites associated with selenites and very reduced marly interlayers (Cattolica Eraclea) or by detritus of these primary deposits (parts of the Capodarso section).

On the other hand, one may find anomalies of sedimentation, such as synsedimentary flows of gypsum material as at Eraclea Minoa or others of intercalated marls as at Passarello/Stretto Vanelle (Figures 3, 4). These greatly influence the evolution of the concentration-controlled process which builds up the major sequence (Mascle and Heimann, in press).

The record of Messinian cyclicity is equally well preserved on the Ionian Islands along the eastern border of the Ionian Sea. Six evaporitic cycles are recorded at Kalamaki (Zakynthos), four at Agios Sostis (Zakynthos) and six to seven again in outcrops of the northern Corfiote Neogene Basin (Heimann et al., 1975). The interpreted environments of deposition of these outcrops range from subaqueous through littoral to sabkha environments. The type of foraminifera faunas in sediments preceding and following the evaporitic intervals suggests water depths between 0 and 200 meters, with 500 meters as the maximum.

\section{Number of Cyclic Events}

Although we observed six to seven cyclic events repeatedly on the Ionian Islands (Braune et al., 1973), this number is not indicative of the whole Mediterranean area. Twelve cycles are described from the Marche-Romagna Area, 17 to 18 from the Adriatic foredeep (Selli, 1973), about 10 from the Great Sicilian Neogene Basin (Heimann and Mascle, 1974), and even as many as 21 from the Ciminna Basin in Northern Sicily (Bonmarito and Catalano, 1973). On the other hand, there may be places where the whole of the evaporitic Messinian is represented by only one evaporitic cycle or even by a single member of an evaporitic sequence as is the case for the "Calcare di base" on the "Raffadali-Armerina Platform" in Sicily (Richter-Bernburg, 1973). An extreme case of lateral differentiation occurs in southern Spain where, in addition to outcrops with evaporites and/or carbonates, a complete Messinian sequence composed essentially of marine marls is exposed (Vera Basin; Montenat et al., 1975). In the western part of Malta and northwest of 
Gozzo, the upper half of a Messinian sequence is composed of blue clays and green sands (G. Mascle, personal communication). In other places (Caltanisetta, Cattoloca Eraclea, Sicily) evaporation continued as mentioned above and resulted in deposition of halite and bitterns which are completely absent on the Ionian Islands.

\section{Evaluation}

Information about the underlying and overlying sediments is indispensable in identifying the original environment of evaporite deposition. This is impossible to obtain from core samples, because contacts between hard sulfate rock and soft marls are intensively disturbed by drilling. From comparisons of the cored material with samples from land sections of Greece and Sicily, we deduce that the Site 374 evaporites were deposited in subaqueous, nearshore, and sabkha environments. The halite at the base of Site 374 was possibly deposited under similar conditions as the halite in Sicily, where large lenses are aligned along the west-southwest/east-northeast running axis which marks the deepest parts of the Great Sicilian Neogene Basin.

More specific interpretation of the investigated samples is, in our opinion, misleading. Evaporite core materials should be interpreted with caution as they represent a very incomplete and local sedimentological record at the drilled site. Although horizontal facies changes are likely to be less important in the middle of a basin than in a marginal setting, it is, in our view, hazardous to consider the recovered cores as representative of a larger area.

These objections arise from our observations in the field. In dozens of cases only a combination of rapidly changing features displayed laterally within a single layer, led to an understanding of the genesis of the sediment. Moreover, the understanding of some pheonomena will always remain questionable and subject to personal interpretation, especially when data are numerous, as in extensive outcrops.

\section{Interim Remarks}

An environmental model applicable to the Messinian "Mediterranean" should encompass the following observations and facts.

1) The beginning and end of the "salinity crisis" are mostly transitional events and there are no "allMediterranean" catastrophic breaks.

2) There are continuous sections of late Miocene marine sediments without evaporites (Vera Basin, Spain; Alboran Sea).

3) Normal marine shallow-water carbonates may be interbedded with the evaporitic sequence (Schreiber and Friedman, 1976) or may even replace it in some areas (Richter-Bernburg, 1973).

4) Besides the entity of the Messinian "salinity crisis," which can be interpreted as one large cyclic event, there are also two other types of cycles of different dimensions: rhythms of millimeters to centimeters and cycles of meters to tens of meters (Heimann and Mascle, 1974).
5) Algal-stromatolitic and anhydrite facies represent sublittoral to littoral and subaerial facies, respectively.

6) A substantial marine influx is needed for the formation of the considerable halite deposits in the deepest parts of the sub-basins. Major reflux of highly concentrated brines throughout the "salinity crisis" must be excluded.

7) Within the Mediterranean region there are large differences in the thickness of the post-sulfate facies (see Figures 3, 4). The Messinian did not in general end with the last deposition of evaporites.

8) Messinian-type evaporites are in existence in strata of the Globorotalia acostaensis Zone, Tortonian (e.g., at Cape Liakas, Cephalonia).

\section{"DEEP" VERSUS "SHALLOW-BASIN MODEL"}

\section{Introduction}

Whether one is in agreement or opposed to the desiccated "deep-basin model" (Hsü, 1973), we must admit that the energy and engaging personalities of these authors induced much of the present activity concerning Neogene geology in the Mediterranean area. Many of their original statements have been questioned in the meantime. We, therefore, must continue to ask whether the "deep-" or "shallow-basin" theory best fits into the framework of geological field and laboratory data.

Although we do not think it necessary to repeat all of the many conflicting arguments (Drooger, 1973; Sonnenfeld, 1974, 1975) we think three aspects are especially critical: the "waterfall," or in other words, the connection of the Mediterranean with the open oceans, and influx and reflux through it; the relationship between the different facies on- and offshore during the Messinian period; the relationship of the "Messinian" to the overlying and underlying strata.

A Messinian deep basin requires certain geographic, oceanographic, and geologic conditions as follows.

1) A pre-existing deep basin at the end of the Tortonian with sills deep enough to allow a balanced influx-reflux system.

2) In late Tortonian/early Messinian times these sills had to shallow considerably or new barriers had to form preventing the reflux of concentrating brines.

3) A waterfall, a system of cascades, or even more complicated, one-way watergates must have existed to provide enormous quantities of oceanic water intermittently and/or continuously.

4) The barrier system must have been extraordinarily resistant to erosion and in action throughout Messinian times; if it were not, one has to assume it was "self-repairing."

5) The basin(s) must have been filled several times "up to the brim" which was followed by desiccation.

6) Repeated regressions to allow desiccation, followed each time by a fast and dramatic transgression, must have occurred in order to produce rises of sea level over several thousand meters. This should have caused the mobilization of huge amounts of debris 
which would result in turbiditic sequences associated with the stages of high sea level.

\section{Connection With the Open Oceans}

According to the data published by Hsü et al. (1973b), and Hsü (1973), the mere water loss by evaporation would require a daily influx of marine water of about $9 \mathrm{~km}^{3}$, or about $100,000 \mathrm{~m}^{3}$ per second (a quantity comparable to that of the Amazon River near Recife), in addition to a supply from rivers and precipitation. If we assume that it would take one to ten thousand years for a single refill of the desiccated basin(s), this quantity must be multiplied. Assuming only one marine watergate, the Gibraltar area, as suggested by Hsü, the erosional potential of 100,000 $\mathrm{m}^{3}$ per second would be sufficient to destroy the barrier within a geologically short time. Hsü's argument of a natural barrier being more resistant than an artificial dam of concrete construction is not convincing. Even if we assume a thickness of about one hundred kilometers for this natural dam, the water, once cascading down the Mediterranean side, would easily find lithologically and tectonically weak zones to cut back a narrow gorge comparable to the Dardanelles and the Bosporus. The result would be a more or less fast rise of the Mediterranean sea level to match the world ocean sea level. Such an inlet, once established, is unlikely to be closed by sedimentation or a tectonic uplift as demonstrated by the aforementioned Black Sea-Mediterranean connection.

The only means of closing such an inlet would be a simultaneous opening of at least one other waterway such that the other inlet would take charge of the entire influx capacity of the closing one. In this case, however, the closure of one gate does not cause a subsidence of the internal sea level.

The development of the western Mediterranean also strongly contradicts the deep-basin model. The recent re-examination of Site 121 samples from the Alboran Sea by Montenat et al. (1975) and the reconstruction of the drowned relief render a substantial sea-level difference between the Atlantic and Mediterranean during Messinian times rather improbable. This part of the Mediterranean most likely originated since the Messinian.

Post-Messinian tectonics created the graben of Gibraltar (Pfannenstiel, 1975) and were responsible for the final disappearance of the former Alboran landmass. In order to save the deep-basin model, one might take this Alboran landmass for the required dam between the Atlantic and the Messinian "Mediterranean." Because of sea-level differences of more than 1000 meters, the Alboran as well as the South-Rifain waterways (the "détroit nord-bétique" which closed at the end of Tortonian) would also have extensively cut back into the Alboran landmass and the African shield. Any other possible sill or dam (see connections in Brinkmann, 1969; Hsul and Bernoulli, this volume) which produced a substantial sea-level difference between the "Mediterranean" and the open ocean(s) would be subject to the same physical process. The importance and exact time of activity of these connec- tions are difficult to evaluate. There is a distinct possibility that more than one might have been active at the same time.

\section{Messinian Near- and Offshore Facies}

Deep-basin desiccation and deep-basin refills imply a separation of facies. The sulfate facies as a product of evaporation (low water level) should be found at a substantial lateral and vertical distance from the littoral facies marking stages of high sea level. At least some of the (up to 21) fillings of the "Mediterranean" each matching the world ocean sea level should have left behind detectable traces. No such separation of facies is known. On the contrary, everywhere in the Mediterranean area where an intra-Messinian littoral facies occurs, these calcareous sediments are intercalated within or at least near the sulfate facies (Perrodon, 1957; Schreiber and Friedman, 1976). Moreover, the existence of a deep basin where evaporites are partly formed subaerially contradicts the occurrence of continuous intrabasinal marine sequences, described by Bizon et al. (1975) and Montenat et al. (1975).

\section{Sedimentary Facies Preceding and Following the Messinian Period \\ Sedimentary Facies and Paleobathymetry at the Tortonian/Messinian Boundary}

The bathymetric interpretation of the marine sediments of late Tortonian time is a key problem. The reconstruction of paleobathymetry is still problematic. Statements such as "pelagic" or "hemipelagic" do not mean anything other than "relating to the open ocean." Even a differentiation between "pelagic" and "neritic" is difficult when dealing with "hemipelagic" sediments. The mere presence of planktonic foraminifers and/or coccoliths is not an absolute bathymetric indication.

The data concerning the Tortonian/Messinian boundary, as gathered by the Deep Sea Drilling Project, are still very scarce. On Leg 13, the "Tortonian" marls of Site 121 (Alboran Sea) did not survive reexamination and proved to be of Messinian age (Montenat et al., 1975). At Site 372 of Leg 42A, the "contact" between Messinian gypsum and the (only slightly dolomitic) underlying nannofossil marls (Tortonian after G. Bizon; Serravallian after M. B. Cita, both this volume) appears to be either a large stratigraphic hiatus or a gap caused by drilling. At Site 375 the actual contact was not drilled. The first Tortonian sediments encountered are a thin limestone breccia topping "flysch-like" nannofossil marls, containing only $0 \%-9 \%$ dolomite and up to $5 \%$ magnesian calcite (Müller, this volume), which probably resulted from their being turbiditic sediments.

Up to Oliogocene time at least the eastern part of the Ionian Sea must have been a platform with reefal and other shallow water environments. In the circumIonian land sections the depositional environment of the uppermost Tortonian sediments is generally interpreted as open-marine but not necessarily as abyssal. On the contrary, the information obtained from these 
land sections can best be compared with the recent regime of sedimentation found offshore in this area in water depths less than 300 meters (Braune, 1971). This relatively shallow depth matches with the occurrence of the lowermost (Tortonian) gypsum layer in the Cape Liakas section of Cephalonia (dated by J. Just, Munich, personal communication). Bergmann (1965), Bizon (1967), Bizon et al. (1969), Braune (1965), Dremel (1970), Hagn et al. (1968), Horstmann (1967), and the authors of an IFP report (1966) investigated the Tortonian sediments of the Ionian Islands, and all found evidence for open marine, but not deepsea conditions.

Data from Sicily indicate that the Tortonian sediments there are not deep-sea sediments either. The early Miocene and Tortonian sediments of the southern foredeep of the Siculo-North African orogenic belt yield the following bathymetric data: 500 meters water depth determined from investigations of early Miocene "Sedimenti Tripolacei"' (Decima and Sprovieri, 1973); a late Tortonian ostracode fauna from blue-grayish marls indicates a water depth of about 600 meters (Decima and Wezel, 1971). Moreover, at different places in Sicily, Tortonian coral reefs are known to exist (Mascle, personal communication). From the western Monti Madonie, Broquet (1971) describes a thick Tortonian marly sequence with arenitic and conglomeratic (partly lenticular) intercalations; the upper 30 meters consist of a conglomerate.

\section{Facies and Bathymetry of Lower Pliocene Sediments}

The facies of lower Pliocene sediments has been used by many authors as another argument in favor of the deep-basin theory. Their arguments are:

1) Inferred discordances, erosional features, or other indicators of important currents at the sea bottom during the earliest Pliocene, give evidence of an almost "all-Mediterranean" deluge of a deep and desiccated Messinian basin(s).

2) The first normal marine sediments are deep basinal ones because of their "pelagic" or "hemipelagic" lithofacies and their content of "pelagic" (= planktonic) foraminifers and coccoliths (see above).

3) The so-called "Trubi" limestone (calcilutites to fine-grained calcarenites), which contain many planktonic foraminifers and coccoliths, are similar to a deepsea foraminiferal ooze.

Most DSDP cores containing the Miocene/Pliocene boundary show dolomitic to dolomite or calcareous marls below the boundary (Figures 3,4). Many of them contain dwarfed planktonic foraminifers. Determination of depositional water depths on the basis of the foraminiferal content of these sediments must be considered with some caution: no recent Mediterranean analog is known. The reliability of extra-Mediterranean standards for a dolomitic sediment of an evaporite cycle is especially poor. Thus, all we know is that the planktonic foraminifers were deposited in depths allowing their general distribution and migration. Late Messinian turbiditic interbeds (at Site 376), possibly derived from nearby Cyprus (Baroz and Bizon, 1974), indicate the existence of a slope and of a (perhaps local) sub-basin. The basin, however, would not have to be very deep.

Generally, the (biostratigraphic) Miocene/Pliocene boundary coincides with the first appearance of "normal" marine planktonic foraminifers. Sedimentologically, neither the DSDP cores nor the land sections indicate a total change of physical environment: only an ecological one. In cores with partial recovery terms like "important gaps," unless documented by hardgrounds, erosional features, or resedimentation, should not be used.

Facies changes diachronously over such a large area as the Mediterranean. Without questioning all gaps, hiatusses in summa, we positively think that the Miocene/Pliocene boundary in the Mediterranean area, in most cases, represents a time of normal development of facies, i.e., that the sequence of facies is in accordance with Walter's law of facies change.

Most land sections show normal sedimentological contacts: Montenat et al., (1975) describe an undisturbed contact of a totally marine sequence in the Vera Basin in Spain. In Sicily, Heimann and Mascle (1974) showed that the so-called discordance between Miocene and Pliocene does not exist all over the island. They indicate normal contacts for outcrops in the Great Sicilian Neogene Basin as do Decima and Sprovieri (1973), Ruggieri and Sprovieri (1974), and Brolsma (1975).

No disturbed contact between Miocene and Pliocene sediments is apparent in the Ionian Islands (Braune et al., 1973). On Crete finally, the boundary between Miocene and Pliocene strata can only be deduced from the sudden occurrence of $G$. margaritae and $G$. subscitula (Meilenkamp and Zachariasse, 1973).

If deep-sea conditions had existed during early Pliocene in the area of the Ionian Islands, evidence for it should be found in the sediment and their faunal content. Neither Bizon and Mirkou (1967), Braune (1971), Horstmann (1967), Hug (1968), Marangoudakis (1960, 1964, 1967), nor Uliczny (1969) discovered evidence for a deep sea in the Ionian area. Marangoudakis (1967) indicates a depositional depth of 50-300 meters for early Pliocene sediments at Corfu. Consequently, we have to infer that a littoral to shelf environment existed during the Pliocene.

In Sicily the same is true. Most data indicate fairly shallow waters (c.f. data in Mascle and Heimann, in press) and the "deep-sea" character of the "Trubi" facies must be questioned. The center of the Ionian basin (Site 374) did not yield much evidence of such a facies. In contrast, in marginal areas (Ionian Islands, Sicily) the "Trubi" facies can be very important. Mascle and Heimann (in press) pointed out that the "Trubi" facies could easily be compared with Cretaceous chalk from the Paris Basin. There, on basis of recent paleontological studies (Aubry, 1972, 1974; Bignot, 1965, 1966, 1968; Bignot and Defretin, 1967), the chalk is interpreted as a moderately shallow facies. Moreover, Mascle and Heimann identified outcrops in Sicily, where "Trubi" interfingers with littoral sedi- 
ments. Broquet (1971), who considered the "Trubi" to be a fully marine sediment of deep waters, admitted that the depositional depth rapidly shallowed on nearing the "continent" (Lascari region, Sicily). Where its deposition exceeds the borders of the evaporitic basins, discordant contacts with the substratum should be observed.

On the Ionian Islands, shallow water sediments interbed within typical "Trubi" limestone. These interbeds do not show turbiditic features. The "Trubi" sediments on Cephalonia are topped by calcarenites with abundant Cardium, Ostrea, and Pecten. On Zakynthos the faunal assemblages in the marl, on top of a 3-meter bed of "Trubi" limestone, indicate a maximum depositional depth of 200 meters (J. Meulenkamp, personal communication). Thus, "Trubi", carbonates were deposited in marine waters below wave base, but probably not deeper than some tens to two hundred meters. Apparently, the "Trubi" facies is typical of marginal areas of a basin, while in the center of the basin (Site 374) argillaceous sediments were deposited.

In summary, the Tortonian/Messinian as well as the Messinian/Pliocene boundaries are transitional and not "catastrophic." They only represent important environmental changes. Late Tortonian was a time of more or less normal marine conditions which changed to a restricted and mainly hypersaline one during the Messinian, then returned again to a normal marine environment since the early Pliocene.

\section{TECTONIC ARGUMENTS}

According to the deep-basin theory, Sicily with its important Messinian halite deposits in the Platani Trough would be among the deepest areas of the Mediterranean region. After Hsü et al. (1973a,b), this would have been more than 2000 meters, perhaps down to 4000 meters below the world ocean sea level. Most of Sicily, however, emerged during Pliocene times (Mascle, 1973, 1974). If Cita (1973) is correct in placing the "Trubi" limestone among the deep-sea oozes, an uplift of some thousands of meters between early to middle (= Trubi) and late Pliocene time is required.

The uplift of Sicily is thought to have been a rather slow one. It was accompanied by important horst-andgraben tectonics, which created traps for huge amounts of Pliocene sediments (Colantoni and Zarudzki, 1973). On the eastern border of the Ionian Sea, similar tectonics took place (IFP, 1966) and continue as "neotectonics" until today (Mercier et al., 1972).

The sedimentologic and tectonic history of the North African basins, reconstructed from land exposures, field, and core data (Perrodon, 1957; Fenet, 1975), does not fit the deep-basin model, either.

The overall development of the western Mediterranean also conflicts with the deep-sea model (Glangeaud, 1961, 1968; Stanley et al., 1974; Pfannenstiel, 1975). The recent re-examination of Site 121 samples (Alboran Sea) by Montenat et al. (1975) and the reconstruction of a drowned paleo-relief render a substantial difference in sea level between the Atlantic and Mediterranean during Messinian times rather difficult to explain. Finally, post-Messinian tectonics not only created the graben of Gibraltar, but were responsible for the configuration of the present-day western Mediterranean (Pfannenstiel, 1975). Our reasons for excluding the Alboran landmass (Pfannenstiel, 1975) as a barrier construction sensu Hsü (1973) are outlined above (Connections with The Open Oceans).

In summary, there are quite a few sedimentologic, tectonic, and paleontologic data from all around the Mediterranean which do not fit the desiccated deepbasin model (Hsü et al., 1973a, b). We therefore disagree with this explanation of the Messinian event in the Mediterranean.

\section{A DYNAMIC MODEL OF SHALLOW BASINAL SETTING AT WORLD OCEAN SEA LEVEL}

This model is characterized by continuous influx of marine waters, blockage of reflux, thick halite deposits in fast subsiding parts, and subaqueous to subaerial deposition of sulfates.

\section{Tortonian}

The Tortonian Sea was slightly larger than the Mediterranean is today (cf. circum-Mediterranean outcrops). Large areas such as parts of the Alboran, Ligurian, and Tyrrhenian (Pfannenstiel, 1975) and the Aegean Sea, however, were land or at least islands in shallow water.

While some onshore outcrops have neritic to littoral facies, some of the sediments at DSDP sites (372 , 375) suggest basinal fillings. Diversification of the sediments, however, indicates that they originated in an environment which is comparable neither in size nor in depth with the Pliocene basins. Influx and reflux seem to have been balanced. Dolomite contents which were higher than in the Recent Mediterranean and thin evaporites (Ionian Islands), suggest the beginning of a restricted regime at the end of the Tortonian. There were certainly connections with the Atlantic and the Paratethys waters.

\section{Messinian}

Eustatic lowering of the world ocean sea level, which reduced the cross-section of the narrows with the Atlantic, and tectonical movements which marked the beginning of a general uplift of Mediterranean marginal areas, may have caused an increase in restriction. The influx was never completely cut off; the reflux, however, ceased during most of the interval. Without any mechanical barrier, an acceleration of the influx into the shallow basin(s) was sufficient to prevent the reflux of hypersaline bottom waters and thus created evaporitic conditions (Sonnenfeld, 1974, 1975).

This shallow sea was spotted with islands, especially in those regions subsiding during Messinian to Pliocene times: the Alboran and Tyrrhenian seas. Corsica, Sardinia, areas of southern Italy, and parts of the Ionian and Aegean regions were islands or land masses at this time. This diversified sea- and landscape pro- 
duced the multitude of facies known in the Messinian record.

In the deepest and fastest subsiding parts of this shallow sea, concentrated brines gathered and formed more than a thousand meters of halite, while in depressions near the basin-inlets, marly sediments were deposited throughout the Messinian. Shallow-water carbonates formed on the rims, probably near the inlets and in areas which were swept by currents. In areas far from the influence of incoming normally saline waters, only the sulfate facies are found.

Times when evaporation predominated alternated with periods in which more normal salinities-either from dilution by fresh or brackish waters or increased influx of oceanic waters-prevailed (biofacies of dwarfed fauna). This mode, favored by the basin's relief, accounts for the differences in number of evaporitic cycles. Climatic changes are less likely causes for these differences (Benda, 1973; Heimann and Jung, 1976).

\section{Pliocene-Quaternary}

There is no reason to retain the idea of a "great deluge" in late Miocene or early Pliocene time. Sedimentologic evidence for an "all-Mediterranean" catastrophy is simply not present. On the contrary, the unusual transition in the cores from a dolomitic mud with a dwarfed, mainly planktonic fauna, to a calcareous marl with a normal marine fauna indicates a gradational sedimentological change and a somewhat faster ecological one. The final foundering of the Alboran Land and the collapse of the Strait of Gibraltar as a tectonic graben probably caused the reestablishment of a reflux-system. As soon as this became effective, the ecological change to a normal marine situation developed.

During early Pliocene, more oxygenated sediments were deposited. Restrictions, indicated by sapropels and sapropelic layers (Sigl et al., this volume) in the eastern Mediterranean, show that a sill between the western and eastern basins restricted the exchange of water: a heavier water body was covered by a lighter one which prevented a vertical exchange for some time.

In the vast area of the Ionian Sea, turbidity currents did not reach the central basin before Quaternary time (Müller et al., this volume). We interpret their appearance as a signal that the present morphology of this part of the Mediterranean Sea was reached.

\section{Rate of Subsidence of the Basins}

During Messinian time, the rate of subsidence of the different sub-basins (Balearic and Ionian-Levantine basins) was about 1000 to less than 2000 meters per 1.8 million years. The basins were filled by 1000 to 2000 meters of evaporites, predominantly chlorides, which compensated for most of the subsidence. Differences in subsidence (and local uplifts) are probably responsible, in part, for the change within the evaporitic facies.

When influx and reflux were again balanced, and consequently deposition of evaporites generally ceased with the Pliocene Mediterranean, neither evaporites nor the generally scarce clastic component could compensate for the continuing subsidence of the centers of the present-day basins. These depressions, therefore, became "starved basins." The rate of subsidence during Pliocene/Quaternary times (3000 to $5000 \mathrm{~m}$ in about 5 million years) did not change considerably compared to that of Messinian time. Probably, the main difference was that in Pliocene time the size of the basins became considerably larger and the margins of the basins more pronounced and steeper than in late Miocene time.

The occurrence of turbidites in Quaternary sediments of Site 374 indicates this steepening and possibly also shows that the present-day morphology of the Mediterranean area is not older than Quaternary.

\section{CONCLUSIONS}

From comparison of Site 374 with circum-Ionian land sections, and taking into account the other DSDP sites of Leg 13 and Leg 42A as well as data in recent publications, we conclude that the Mediterranean evaporites were formed in an area at or near world ocean sea level. The depth of the basins, which marks a large tectonic contact zone between Africa and Europe, did not exceed a few hundred meters during Messinian time.

The connections to the open oceans have never closed completely, and the basins were almost constantly filled by seawater. We regard the existence of a waterfall or systems of cascading waterways which would have had to supply water at about $10^{5} \mathrm{~m}^{3}$ per second to balance evaporation, while not destroying their barrier, as impossible.

The studies of sedimentary facies yield other important evidence for the existence of a dynamic shallow basin during the Messinian. The coexistence of fully marine marly sequences, alongside and interfingering with marine shallow-water carbonates, which pass laterally into the evaporitic facies, can only be explained by a constant influx into the Mediterranean Basin. The lack of reflux of high salinity brines because of shallow sills to the oceans, combined with fast influx currents, caused the deposition of thick halite, and of sulfates and dolomitic marls.

A shallow basin and great thickness of evaporites can only be explained by synsedimentary subsidence. The average rate of subsidence was probably about 1 meter per 1000 years during the Messinian, thus showing a comparable depth at the beginning and the end of the late Miocene. The lowering of the Messinian basins to their present depth implies that the rate of subsidence was about the same during the PlioceneQuaternary time, but that sediment accumulation did not keep pace with subsidence (starved basin) during this time.

A more or less continuous subsidence of the Mediterranean region since late Miocene time neither necessitates complicated tectonic mechanisms to repeatedly move up and down a barrier system between the Mediterranean and the Atlantic, nor does it require elevation of separated tectonic units from the bottom 
of the deep sea to their present position (e.g., Sicily, Greece, Crete, and many of the marginal areas).

We consider the subsidence of large Mediterranean areas since the late Miocene as an expression of largescale tensional movement. Nevertheless, not all the basins subsided at the same time: while thick evaporites in the Balearic and Ionian/Levantine basins indicate a relatively early and fast subsidence during the late Miocene, parts of the Alboran and the Tyrrhenian areas remained elevated up to the beginning of Messinian and Pliocene times, respectively.

\section{ACKNOWLEDGMENTS}

We are grateful to Drs. W. Hieke, J. Müller, and W. Sigl (all Munich) for interesting discussions. We thank Drs. M. J. Brolsma, Utrecht, and G. Mascle, Paris, for critically reviewing the manuscript. Financial support was given by Deutsche Forschungsgemeinschaft, a special grant of which allowed the senior author to participate on Leg 42A.

\section{REFERENCES}

Aubry, M. P., 1972. Recherches petrographiques, stratigraphiques et paleosedimentologiques sur les craies de Haute Normandie: Thèse, Paris, p. 1-105.

1974. Application du microscope electronique a balayage (MEB) à la paleontologie et à la sédimentologie: Trav. Lab. Micropal., Univ. Paris VI, no. 3, p. 225-295.

Baroz, F. and Bizon, G., 1974. Le Neogène de la Chaine du Pentadaktylos et de la Partie Nord de la Mesaoria (Chypre) - Etude Stratigraphique et Micropaleontologique: Rev. l'Institut Francais du Pétrole, v. 29, p. $327-$ 348.

Benda, L., 1973. Late Miocene sporomorph assemblages from the Mediterranean and their possible paleoclimatological implications. In Drooger, C. W. (Ed.), Messinian events in the Mediterranean: Amsterdam (Kon. Ned. Akad. Wetensch.), p. 256-259.

Bergmann, H., 1965. Die Geologie und Stratigraphie der Paxos-Zone in Nord-Kephallinia; Dipl. Arbeit., Universität München, unpublished, p. 1-93.

Bignot, G., 1965. Remarques sur les Brachiopodes de la craie de la region de Dieppe (S.M.): Soc. Geol. Normandie Bull., v. 55, p. 4-14

1966. Remarques sur les Lamellibranches de la craie de la region de Dieppe: Soc. Geol. Normandie Bull., v. 56, p. $15-23$.

1968. Remarques sur quelques Serpulides de la craie de la region de Dieppe: Soc. Geol. Normandie Bull., v. 58, p. $17-29$.

Bignot, G. and Defretin, S., 1967. Remarques sur les Spongiaires siliceux de la craie de la region de Dieppe: Soc. Geol. Normandie Bull., v. 57, p. 9-14.

Bizon, G., 1967. Contribution à la connaissance des foraminifères planctoniques d'Epire et des Iles Ioniènnes: Paris (Editions Technip.), p. 1-142.

Bizon, G. and Mirkou, R., 1969. Les foraminifères du Pliocene de l'ile de Zante: First Intern. Conf. Plankt. Microf. Proc., Geneva, 1967, v. 1, Leiden (Brill), p. 179189.

Bizon, J. J., Bizon, G., and Horstmann, G., 1969. Les foraminifères planctoniques du Miocène de l'ile de Zante: First Intern. Conf. Plankt. Microf. Proc., Geneva, 1967, v. 1, Leiden (Brill), p. 190-198.

Bizon, G., Bizon, J. J., and Montenat, C., 1975. Définition biostratigraphique du Messinien: C.R. Acad. Sci. Paris., v. 281 , p. $359-362$.
Bommarito, S. and Catalano, R., 1973. Facies Analysis of an Evaporitic Messinian Sequence near Ciminna (Palermo/ Sicily). In Drooger, C. W. (Ed.), Messinian events in the Mediterranean: Amsterdam (Kon. Ned. Akad. Wetensch.), p. 172-177.

Braune, K., 1965. Geol. Pal. Untersuchungen im SE de Insel Kephallinia: Unpublished, Universität München, p. 1-80. 1971. Die rezenten und pleistozanen sedimente des sublitorals von Kephallinia (Ionische Inseln): Diss. TU München; short version, same title, Senckenbergiana marit. 5, Frankfurt, 1973 , v. 5, p. 99-133.

Braune, K. and Heimann, K. O., 1973. Miocene evaporites on the Ionian Islands: Geol. Soc. Greece Bull., v. 10, p. 25-30.

Braune, K., Fabricius, F., and Heimann, K. O., 1973. Sedimentation and facies of late Miocene strata on Cephalonia (Greece). In Drooger, C. W. (Ed.), Messinian events in the Mediterranean: Amsterdam (Kon. Ned. Akad. Wetensch.), p. 192-201.

Brinkmann, R., 1969, Abriss der Geologie. In Enke, F. (Ed.), Historische Geologie, Stuttgart.

Brolsma, M. J., 1975: Lithostratigraphy and foraminiferal assemblages of the Miocene-Pliocene transitional strata of Capo Rossello and Eraclea Minoa (Sicily, Italy): Proc. Kon. Ned. Akad. Wetensch, B., v. 78, p. 341-380.

Broquet, P., 1971. Etude géologique de la Région des Madonies (Sicile): Thèse, I.R.E.S. Palermo, v. 1, p. 1-333.

Busson, G., and Noèl, D., 1972. Sur la constitution et la genèse de divers sédiments finement feuilletés ("laminites”): C. R. Acad. Sci. Paris, v. 274, p. 3172-3175.

Busson, G., Ludlam, S. D., and Noë1, D., 1972. L'importance des Diatomées dans les dépôts actuels varvés de Green Lake: C. R. Acad. Sci. Paris, v. 274, p. 3044-3047.

Butler, G. P., 1969. Modern evaporite deposition and geochemistry of coexisting brines, the Sabkha: J. Sediment. Petrol., v. 39, p. 70-89.

Cita, M. B., 1973. Mediterranean Evaporite: Paleontological arguments for a deep basin desiccation model. In Drooger, C. W. (Ed.), Messinian events in the Mediterranean: Amsterdam (Kon. Ned. Akad. Wetensch.), p. 206-228.

Colantoni, P. and Zarudzki, E. F. M., 1973. Some principal sea floor features in the Strait of Sicily: Geol. Soc. Greece Bull., v. 10, p. 204-205.

Curtis, R., Evans, G., Kinsman, D. J. J. and Shearman, D. J., 1963. Association of Dolomite and Anhydrite in the Recent Sediments of the Persian Gulf: Nature, v. 197, p. $679-680$

1973. Late Miocene evporites of the Central Sicilian Basin, Italy: In Ryan, W. B. F., Hsü, K. J., et al., Initial Report of the Deep Sea Drilling Project, Volume 13: Washington (U. S. Government Printing Office), p. $1251-1256$

Decima, A. and Sprovieri, R., 1973. Presenza di sedimenti tripolacei basso-miocenici in Sicilia: Riv. Mineraria Siciliana, v. 24 , p. $202-212$.

Decima, A. and Wezel, F. C., 1971. Osservazioni sulle evaporiti messiniane della Sicilia centro-meridionale. Riv. Mineraria Siciliana, v. 22, p. 172-187.

Dremel, G., 1970. Das Miozän von Kephallinia, Ionische Inseln, Griechenland: Mitt. Bayer. Staatss. Paläont. Hist. Geol, v. 10, p. 3-86.

Drooger, C. W., 1973. The Messinian events in the Mediterranean. A Review. In Drooger, C. W. (Ed.), Messinian Events in the Mediterranean: Amsterdam (Kon. Ned. Akad. Wetensch.), p. 263-272.

Edinger, S. E., 1973. The growth of gypsum: J. Cryst. Growth, v. 18 , p. $217-224$. 
Fenet, B., 1975. Recherches sur l'alpinisation de la bordure septentrionale du Bouclier Africain: Thèse, Université de Nice, Nice.

Glangeaud, L. 1961. Océanographie géologique et geographie de la Méditerranée occidentale: Coll. Nat. CNRS, Villefranche s.Mer, 125, p. 165.

1968. Les méthodes de la géodynamique et leurs applications aux structures de la Méditerranée occidentale: Rev. Géogr. Phys. Géol. Dyn., v. 10, p. 83-135.

Hagn, H., Bergmann, H., Bischoff, B., Braune, K., Hug, F., and Ott, W., 1968. Zur Neogenstratigraphie von Kephallinia u. Ithaka: Giorn. Geol., v. 35, p. 179-188.

Heimann, K. O., 1975. Comparison of late Miocene evaporitic strata in Sicily and on the Ionian Islands (Abstract); Rapp. Comm. int. Mer Médit., v. 23, p. 147.

1977. Die Fazies des Messins und Untersten Pliozäns auf den Ionischen Inseln (Zakynthos, Kephallinia, Korfu/Griechenland) und auf Sizilien: Thesis, Tech. Universität München, p. 1-158. in press. The Messinian evaporites of the Ionian Islands Zakynthos, Kephallinia and Corfu (Greece). (Abstract): First Messinian Seminar, Erice, Italy, October 1975.

Heimann, K. O. and Jung, W., 1976. Der Evaporitzyklus II bei Paghi, Nord-Korfu. Mitt. Bayer. Staatssamml. Paläont. Hist. Geol., v. 16, 0.00-0.00, München.

Heimann, K. O. and Mascle, G. H., 1974. Les séquences de la série évaporitique messinienne: C. R. Acad. Sci. Paris, v. 279 , p. $1967-1990$.

Heimann, K. O., Jung. W., and Braune, K., 1975. Schichtenfolge und Flora des Messiniens von Nord-Korfu (Griechenland): Mitt. Bayer. Staatssamml. Palaont. hist. Geol., v. 15 , p. $169-177$.

Horstmann, G., 1967: Géologie de la partie méridionale de l'ile de Zante (Grèce), Thèse, Université Paris, p. 1-127.

Hsü, K. J., 1972. When the Mediterranean dried up: Sci. Am., v. 227 , p. $27-36$

1973. The desiccated deep-basin model for the Messinian Events. In Drogger, C. W. (Ed.), Messinian events in the Mediterranean: Amsterdam (Kon. Ned. Akad. Wetensch.), p. 33-59.

Hsü, K. J., Cita, M. B., and Ryan, W. B. F., 1973a. The origin of the Mediterranean evaporites. In Ryan, W. B. F., Hsü, K. J., et al., Initial Reports of the Deep Sea Drilling Project: Volume 13: Washington (U.S. Government Printing Office), p. 695-708.

Hsü, K. J., Ryan, W. F. B., and Cita, M. B., 1973b. Late Miocene desiccation of the Mediterranean: Nature, v. 242, p. 240-244.

Hug, F., 1969. Das Pliozän von Kephallinia (Ionische Inseln). Diss. Universität München, p. 1-128.

I. F. P., 1966. Etude Géologique de l'Epire; Réalisée par l'Inst. Geol. Recherches Sous-sol Athènes et l'Inst. Francais du Pétrole, Mission Grèce: Paris (Editions Technip), p. 1-306.

Kendall, G. S. C., and Skipwith, P. A. D. E., 1969. Holocene Shallow-water Carbonate and Evaporite Sediments: Am. Assoc. Petrol. Geol. Bull., v. 53, p. 841-869.

Kinsman, D. J. J., 1964. Recent carbonate sedimentation near Abu Dhabi, Trucial Coast, Persian Golf: Thesis, Imperial College, London, unpublished.

1965. Dolomitization and Evaporite Development, including anhydrite in Lagoonal Sediments, Persian Gulf. Geol. Soc. Am. Spec. Paper, v. 82, p. 108-109.

1969. Modes of formation, sedimentary associations and diagnostic features of shallow-water and suprat- idal evaporites: Am. Assoc. Petrol. Geol. Bull., v. 53, p. 830-840.

Marangoudakis, N., 1960. The Neogene Foraminifers of Corfu Island: Soc. Geol. Grece Bull., v. 4, p. 65-68.

1964. Geological and micropalaeontological observations concerning Corfu Island: Soc. Geol. Grece Bull., v. 4, p. 1-13.

1967. Geology and Micropaleontology of Corfu Island: Geol. Geophys. Res., v. 12, p. 1-132.

Mascle, G. H., 1973. Etude Géologique des Monts Sicani, Sicile: Thèse, Univ. Paris VI, p. 1-691.

1974. Les grands traits de l'évolution géologique des Monts Sicani, Sicile: Soc. Geol. France Bull., v. 16, p. 161-170.

Mascle, G. H. and Heimann, K. O., in press. Geological observations from Messinian and Lower Pliocene outcrops in Sicily: Contrib. 1. Messinian Seminar, Erice, Italy, October 1975.

Mascle, G. H. and Mascle, J., 1971. Comparaison de la série à gypse sicilienne et des structures évaporitiques de Méditerranée occidentale: C. R. Acad. Sci. Paris, v. 273, p. 2426-2428.

Mercier, J., Bousquet, B., Delibasis, N. Drakopoulos, J., Keraudren B., Lemeille, F., and Sorel, D., 1972. Deformations en compression dans le Quaternaire des rivages ioniens: C. R. Acad. Sci. Paris, v. 275, p. 2307-2310.

Meulenkamp, J. and Zachariasse, W. J., 1973. Stratigraphical and structural framework of the Messinian deposits on Crete. In Drooger, C. W. (Ed.), Messinian events in the Mediterranean: Amsterdam (Kon. Ned. Akad. Wetensch.), p. 202-205.

Milliman, J. D., and Müller, J., 1973. Precipitation and lithification of magnesian calcite in the deep-sea sediments of the eastern Mediterranean Sea: Sedimentology, v. 20, p. $29-45$.

Montadert, L. et al, 1970. De l'âge tertiaire de la série salifêre responsable des structures diapiriques en Méditerranée Occidentale: C. R. Acad. Sci. Paris, v. 271, p. 812.

Montenat, C., Bizon, G., Bizon, J. J., 1975. Rémarques sur le Néogèe du forage Joides 121 en mer d'Alboran: Soc. Geol. France Bull., v. 17, p. 45-51.

Morris, R. C. and Dickey, P. A., 1957. Modern evaporite deposition in Peru: Am. Assoc. Petrol. Geol. Bull., v. 41, p. 2467-2474.

Müller, J. and Fabricius, F., 1973. Carbonate Mineralogy of Deep-Sea Sediments from the Ionian Sea: Rapp. Comm. Int. Mer Médit., v. 21, p. 855-859.

Neev, D., 1963. Recent precipitation of calcium salts in the Dead Sea: Res. Counc. Israel Bull., v. 11, p. 153-154.

Nesteroff, W. D., 1973. Un modèle pour les évaporites messiniennes en Méditerranée des bassins peu profonds avec dépot d'evaporites lagunaires. In Drooger, C. W. (Ed.), Messinian events in the Mediterranean: Amsterdam (Kon. Ned. Akad. Wetensch.), p. 68-81.

Ogniben, L., 1957. Petrografia della Serie Solfifera Siciliana e considerazioni geologiche relative: Mem. Descr. Carta Geol. Ital., v. 33, p. 9-275.

Perrodon, A., 1957. Etude géologique des bassins néogènes sublittoraux de l'Algérie Occidentale: Publ. Serv. Carte Géol. Algérie, v. 12, p. 1-328.

Pfannenstiel, M., 1975. Die Entstehung des Alboranmeeres aus dem alten Alboranland. Ein Beitrag zur Geotektonik des westlichen Mittelmeeres: Memoires de l'Institut Océanographique, v. 8, p. 1-70.

Richter-Bernburg, G., 1973. Facies and Palaeongeography of the Messinian Evaporites in Sicily. In Drooger, C. W. 
(Ed.), Messinian events in the Mediterranean: Amsterdam (Kon. Ned. Akad. Wetensch.), p. 124-141.

Ruggieri, G. and Sprovieri, R., 1974. The lacustrine faunas in Sicily and the desiccation theory of Messinian salinity crisis: Lavori Inst. Geol., Univ. Palermo, v. 13, p. 3-6.

Ryan, W. B. F., 1973. Geodynamic implications of the Messinian crisis of salinity. In Drooger, C. W., (Ed.), Messinian events in the Mediterranean: Amsterdam (Kon. Ned. Akad. Wetensch.), p. 20-38.

Schreiber, B. C., 1974. Upper Miocene (Messinian) Evaporite Deposits of the Mediterranean Basin and their depositional environments: Thesis, Rensselaer Polytechnic Institute.

Schreiber, B. G., and Friedman, C. M., 1976. Depositional environments of Upper Miocene (Messinian) evaporites of Sicily as determined from analysis of intercalated carbonates: Sedimentology, v. 23, p. 255-270.

Selli, R., 1960. Il Messiniano Mayer-Eymar 1867, Proposta di un Neostratotipo: Giorn. Geol., v. 28, p. 1-33.

1973. An outline of the Italian Messinian. In Drooger, C. W., (Ed.), Messinian events in the Mediterranean: Amsterdam (Kon. Ned. Akad. Wetensch.), p. 150170.
Sherman, D. J., 1966. Origin of marine evaporites by diagenesis: Inst. Mining Metallurgy Trans., v. 75, p. 208-215. , 1971. Marine evaporites, the calcium sulphate facies: Univ. Calgary, ASPG Seminar, p. 1-66.

Sonnenfeld, P., 1974. The Upper Miocene evaporites in the Mediterranean Region-a study of paleo-oceanography: Geol. Rundschau, v, 63, p. 1133-1172.

1975. The significance of upper Miocene (Messinian) evaporites in the Mediterranean sea: J. Geol., v. 83, p. 287-311.

Stanley, D. J., Got, H., Leenhardt, O., and Weiler, Y., 1974. Subsidence of the Western Mediterranean Basin in Pliocene-Quaternary Time: further evidence: Geology, p. 345350 .

Uliczny, F., 1969. Hemicytheridae und Trachyleberididae (Ostracoda) aus dem Pliozän der Insel Kephallinia: Dissertation Universität München, p. 1-152.

Wells, A. J. and Illing, L. V., 1964. Present-day precipitation of calcium carbonate in the Persian Gulf: In Van Straaten (Ed.), Development in Sedimentology, Deltaic and shallow marine deposits: Amsterdam (Elsevier), v. 1, p. 429435. 